\title{
Determination of Some Pollutant Gases in Ambient Air of the Vicinity of a Kaolin Milling Plant in Alkaleri, Bauchi State, Nigeria
}

\author{
Abdullahi A.O ${ }^{1}$, Maitera O. $\mathrm{N}^{2}$, Maina H. $\mathrm{M}^{2}$, J.M. Yelwa ${ }^{2}$ \\ ${ }^{1}$ Department of Chemistry, Gombe state University, Gombe, Nigeria \\ ${ }^{2}$ Department of Chemistry, Modibbo Adama University of Technology Yola, Adamawa State, Nigeria \\ *Corresponding Author: Abdullahi A.O, Department of Chemistry, Gombe state University, Gombe, \\ Nigeria
}

\begin{abstract}
The air quality within the vicinity of a Kaolin milling plant in Alkaleri Bauchi State was investigated. Twelve sampling points (SPI - SP12), $2 \mathrm{Km}$ apart at four (4) different directions were considered. A portable gas monitor manufactured by crown instrument Ltd Oxon CE-89/336/EEC for each gas was used to determine the levels of $\mathrm{CO}, \mathrm{NO}_{2}, \mathrm{SO}_{2}$. The results showed the mean concentrations of $\mathrm{CO}$ as $6.81 \pm 2.05 \mathrm{ppm}$ in the dry season and $6.50 \pm 2.50 \mathrm{ppm}$ in the wet season, $\mathrm{NO}_{2}$ mean concentrations as 0.053 $\pm 0.047 \mathrm{ppm}$ in the dry season and $0.04 \pm 0.026 \mathrm{ppm}$ in the wet season and the mean concentration of $\mathrm{SO}_{2}$ as $0.056 \pm 0.045 \mathrm{ppm}$ in the dry season and $0.041 \pm 0.045 \mathrm{ppm}$ in the wet season. No significant difference in the pair wise mean seasonal variation in concentration of $\mathrm{NO}_{2}$ and $\mathrm{SO}_{2}$ at all sampling points except for SP4 but the mean seasonal variation of the level of $C O$ at all the sampling points were statistically significant except for SP9 $(P<0.05)$. The Air quality index $(A Q I)$ of all the pollutants was at the region of Unhealthy for sensitive groups at SP1 and SP4 while at other sampling points it was from Moderate to Good. The study therefore concludes the activity of the Kaolin milling plant can be a source of air pollution with possible health consequences.
\end{abstract}

Keywords: Pollutant Gases, Ambient air, Kaolin, Gas monitor, Milling plant.

\section{INTRODUCTION}

The activities of a Kaolin milling industry can result in air pollution. Air Pollution results mainly from gaseous emission of industries, thermal power stations, automobiles, domestic combustion etc which sources are natural as well as anthropogenic (Narayanan, 2009). Industrial pollution is one of the primary sources of environmental contamination. Factories pollute the air through fossil fuel emissions. Combustion creates toxic pollutants. Gases such as Oxides of Nitrogen $\left(\mathrm{NO}_{\mathrm{x}}\right)$, Oxides of Sulphur $\left(\mathrm{SO}_{\mathrm{x}}\right)$ and Carbon monoxide (CO) may constitute some forms of pollutants. Presence of atmospheric air contaminants in such quantities and duration that may tend to be injurious to life or properties, health repose and safety constitute air pollution. Carbon monoxide (CO) is formed primarily by incomplete combustion of carbon containing fuels and photochemical reactions in the atmosphere. At times forest fires can be an important natural source of CO. By far the most important source of CO emissions to the atmosphere are from transportation. (Kindzierski, et al., 2009). Carbon monoxide can adversely affect the cardiovascular and central nervous systems. Carbon monoxide enters the bloodstream through the lungs and binds to hemoglobin, this reduces the amount of oxygen reaching the body's organs and tissues (US EPA, 2014).

High temperature combustion of hydrocarbon fuel sources such as gasoline, coal, and oil with air produce $\mathrm{NO}$ and smaller quantities of $\mathrm{NO}_{2}$ from reactions between the oxygen and nitrogen present in the combustion air. Most of the $\mathrm{NO}$ in ambient air rapidly turns into $\mathrm{NO}_{2}$. High temperature combustion of hydrocarbon fuel sources such as coal and oil can produce sulphur dioxide $\left(\mathrm{SO}_{2}\right)$ and sulphur trioxide $\left(\mathrm{SO}_{3}\right)$ from the oxidation of any sulphur in these fuels (Kindzierski, et al., 2009). Emissions of these sulphur compounds are associated with industrial operations and contribute to the majority of $\mathrm{SO}_{2}$ emissions from man's activities (Kindzierski, et al., 2009). Long-term exposure to sulphur dioxide may cause respiratory symptoms and illness, and aggravate asthma (US EPA, 2014). 
Determination of Some Pollutant Gases in Ambient Air of the Vicinity of a Kaolin Milling Plant in Alkaleri, Bauchi State, Nigeria

The air quality index (AQI) is an index for reporting daily air quality use in measuring the levels of common air pollutants. It tells how clean or polluted air is, and what associated health effect might be of concern. The AQI is divided into six categories, each category corresponds to a different level of health concern. AQI 0-50 is "Good', 51-100 is "Moderate", 100-150 is "Unhealthy for sensitive group", 151-200 is "Unhealthy", 201-300 is "Very unhealthy" and >300 is "Hazardous" ( US EPA, 2014). This research is therefore aimed at determining the levels of the gases with a view to ascertain the air quality in the vicinity of the Kaolin milling plant.

\section{Materials ANd Methods}

\subsection{Materials and Equipment}

A portable gas monitor manufactured by crown instrument Ltd Oxon CE-89/336/EEC for each gas was used

\subsection{Study Area}

The kaolin milling plant is situated along Gombe-Bauchi road about $5 \mathrm{Km}$ to Alkaleri township. Alkaleri is a town in Alkaleri Local Government Area of Bauchi State, Nigeria. It is on the A345 highway in the north of the area at $10^{\circ} 15^{\prime} 58^{\prime \prime} \mathrm{N} 10^{\circ} 20^{\prime} 07^{\prime \prime} \mathrm{E} / 10.26611^{\circ} \mathrm{N} 10.33528^{\circ} \mathrm{E}$. Figure 1 shows the vicinity of the Kaolin Milling Plant in Alkaleri with the sampling location.

Table1. Sampling location/points at the vicinity of Kaolin milling Plant

\begin{tabular}{|l|l|l|}
\hline Sampling points & Direction from milling plant & Distance from milling plant \\
\hline SP1 & Northwest & $0 \mathrm{Km}$ \\
\hline SP2 & Northwest & $2 \mathrm{Km}$ \\
\hline SP3 & Northwest & $4 \mathrm{Km}$ \\
\hline SP4 & Northeast & $0 \mathrm{Km}$ \\
\hline SP5 & Northeast & $2 \mathrm{Km}$ \\
\hline SP6 & Northeast & $4 \mathrm{Km}$ \\
\hline SP7 & Southwest & $0 \mathrm{Km}$ \\
\hline SP8 & Southwest & $2 \mathrm{Km}$ \\
\hline SP9 & Southwest & $4 \mathrm{Km}$ \\
\hline SP10 & Southeast & $0 \mathrm{Km}$ \\
\hline SP11 & Southeast & $2 \mathrm{Km}$ \\
\hline SP12 & Southeast & $4 \mathrm{Km}$ \\
\hline
\end{tabular}

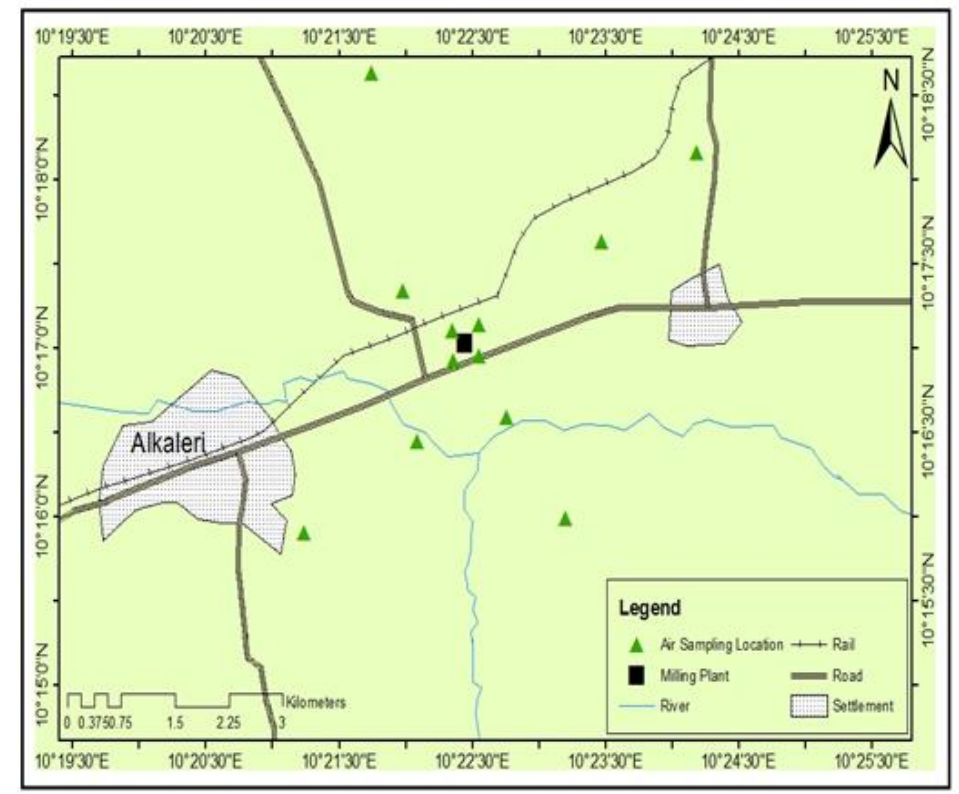

Figure1. The Kaolin Milling Plant and the Air Sampling Location

\subsection{Method of Investigation}

The concentration of $\mathrm{CO}, \mathrm{NO}_{2}$ and $\mathrm{SO}_{2}$, were determined using standard method with the gas monitor at each sampling points in the vicinity of the Kaolin milling Plant. The determinations were carried 
Determination of Some Pollutant Gases in Ambient Air of the Vicinity of a Kaolin Milling Plant in Alkaleri, Bauchi State, Nigeria

out in the month of March for the dry season and the month of June for wet season. US EPA (2016) Airnow air quality index calculator was used to calculate the air quality index of each gas.

\section{RESULTS AND DISCUSSION}

Table2. Concentration of gases in ppm from the vicinity of Kaolin milling Plant

\begin{tabular}{|l|l|l|l|l|l|l|}
\hline Sampling points & \multicolumn{2}{l}{$\mathrm{CO}(\mathrm{ppm})$} & $\mathrm{NO}_{2}(\mathrm{ppm})$ & \multicolumn{2}{l|}{$\mathrm{SO}_{2}(\mathrm{ppm})$} \\
\hline & Dry season & Wet season & Dry season & Wet season & Dry season & Wet season \\
\hline SP1 & $8.33 \pm 0.58$ & $10.8 \pm 0.66$ & $0.11 \pm 0.04$ & $0.077 \pm 0.02$ & $0.147 \pm 0.02$ & $0.12 \pm 0.01$ \\
\hline SP2 & $7.77 \pm 0.15$ & $6.67 \pm 0.58$ & $0.033 \pm 0.02$ & $0.03 \pm 0.02$ & $0.034 \pm 0.01$ & $0.03 \pm 0.01$ \\
\hline SP3 & $6.00 \pm 1.00$ & $7.17 \pm 0.15$ & $0.013 \pm 0.006$ & $0.02 \pm 0.01$ & $0.02 \pm 0.01$ & $0.007 \pm 0.006$ \\
\hline SP4 & $8.00 \pm 1.00$ & $11.97 \pm 0.21$ & $0.147 \pm 0.02$ & $0.06 \pm 0.01$ & $0.163 \pm 0.04$ & $0.117 \pm 0.08$ \\
\hline SP5 & $8.43 \pm 0.45$ & $6.67 \pm 0.58$ & $0.053 \pm 0.02$ & $0.033 \pm 0.02$ & $0.057 \pm 0.02$ & $0.06 \pm 0.04$ \\
\hline SP6 & $7.3 \pm 0.3$ & $6.40 \pm 0.87$ & $0.02 \pm 0.01$ & $0.013 \pm 0.006$ & $0.04 \pm 0.01$ & $0.027 \pm 0.01$ \\
\hline SP7 & $8.5 \pm 0.26$ & $7.33 \pm 0.58$ & $0.08 \pm 0.05$ & $0.077 \pm 0.006$ & $0.063 \pm 0.02$ & $0.03 \pm 0.02$ \\
\hline SP8 & $4.33 \pm 0.35$ & $3.33 \pm 0.58$ & $0.04 \pm 0.03$ & $0.04 \pm 0.02$ & $0.023 \pm 0.01$ & $0.013 \pm 0.02$ \\
\hline SP9 & $3.7 \pm 0.36$ & $3.33 \pm 0.58$ & $0.013 \pm 0.006$ & $0.033 \pm 0.032$ & $0.02 \pm 0.0$ & $0.007 \pm 0.006$ \\
\hline SP10 & $6.00 \pm 0.0$ & $8.1 \pm 0.36$ & $0.07 \pm 0.05$ & $0.06 \pm 0.02$ & $0.07 \pm 0.02$ & $0.05 \pm 0.02$ \\
\hline SP11 & $6.3 \pm 0.46$ & $5.33 \pm 0.58$ & $0.05 \pm 0.03$ & $0.02 \pm 0.006$ & $0.02 \pm 0.006$ & $0.02 \pm 0.01$ \\
\hline SP12 & $4.57 \pm 0.25$ & $3.33 \pm 0.58$ & $0.013 \pm 0.006$ & $0.017 \pm 0.006$ & $0.013 \pm 0.006$ & $0.01 \pm 0.01$ \\
\hline CONTROL & 0.60 & 0.40 & 0.00 & 0.00 & 0.00 & 0.00 \\
\hline
\end{tabular}

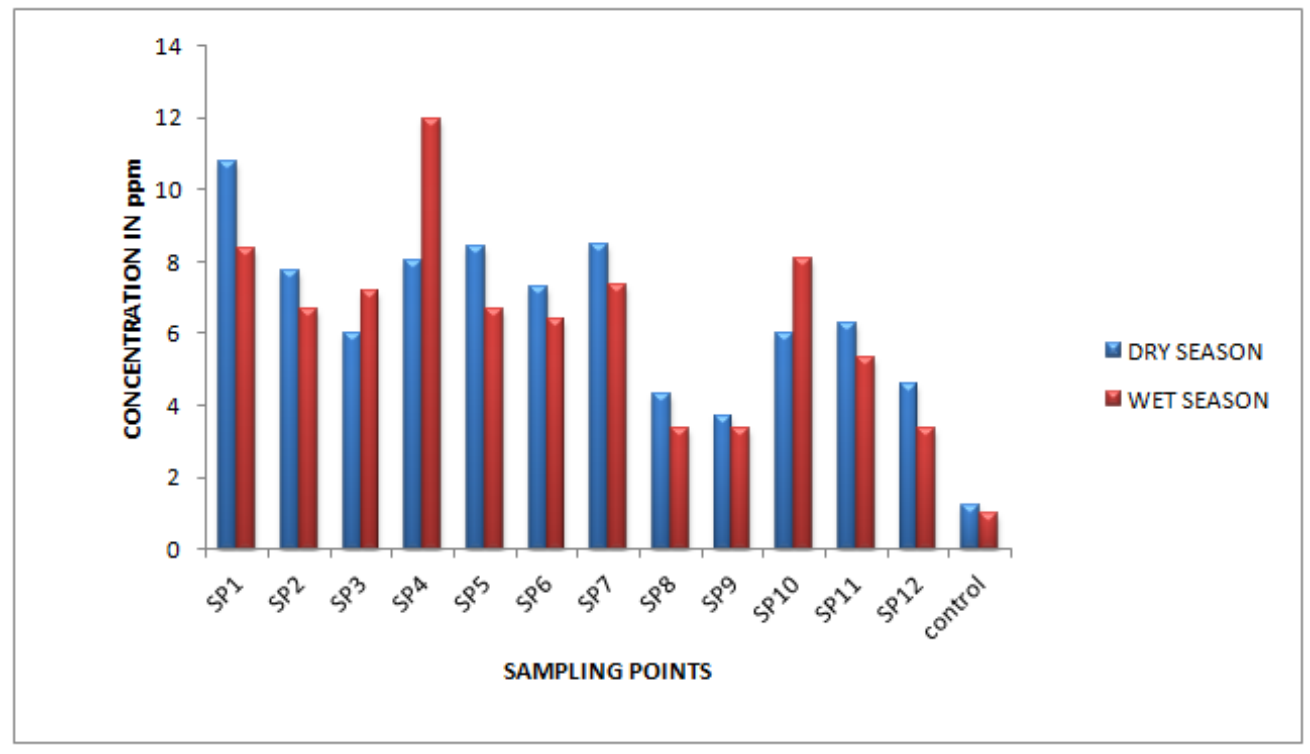

Figure2. Distribution of $\mathrm{CO}$ in some locations within the vicinity of Kaolin milling plant

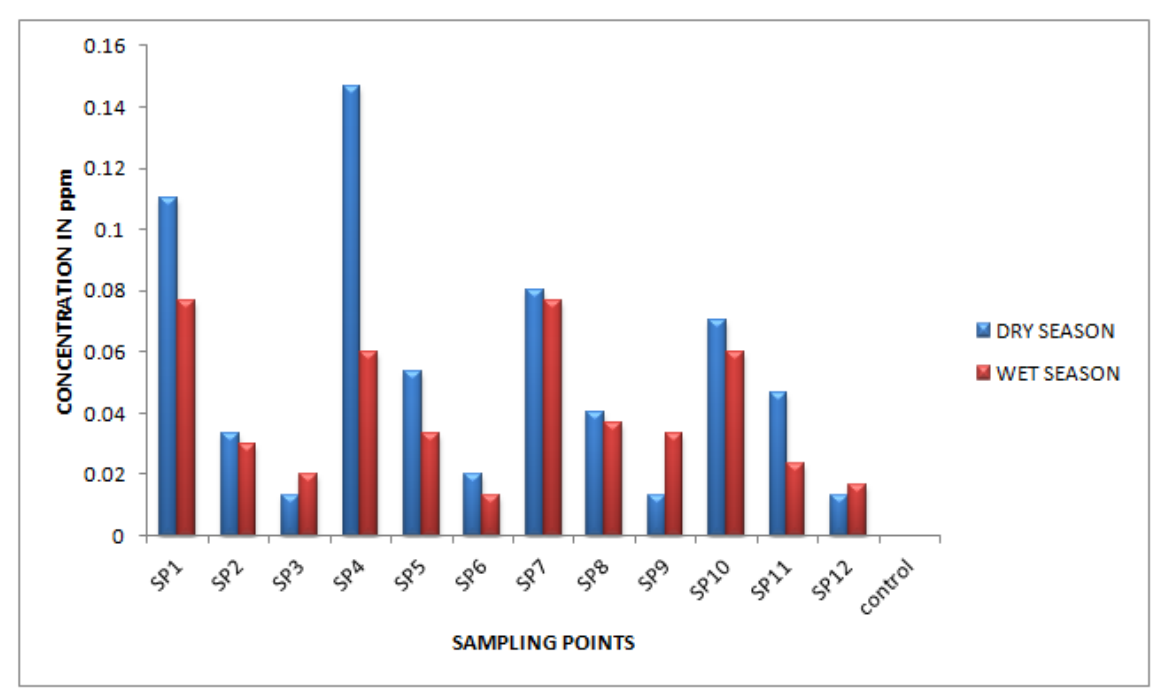

Figure3. Distribution of $\mathrm{NO}_{2}$ in some locations within the vicinity of Kaolin milling plant 


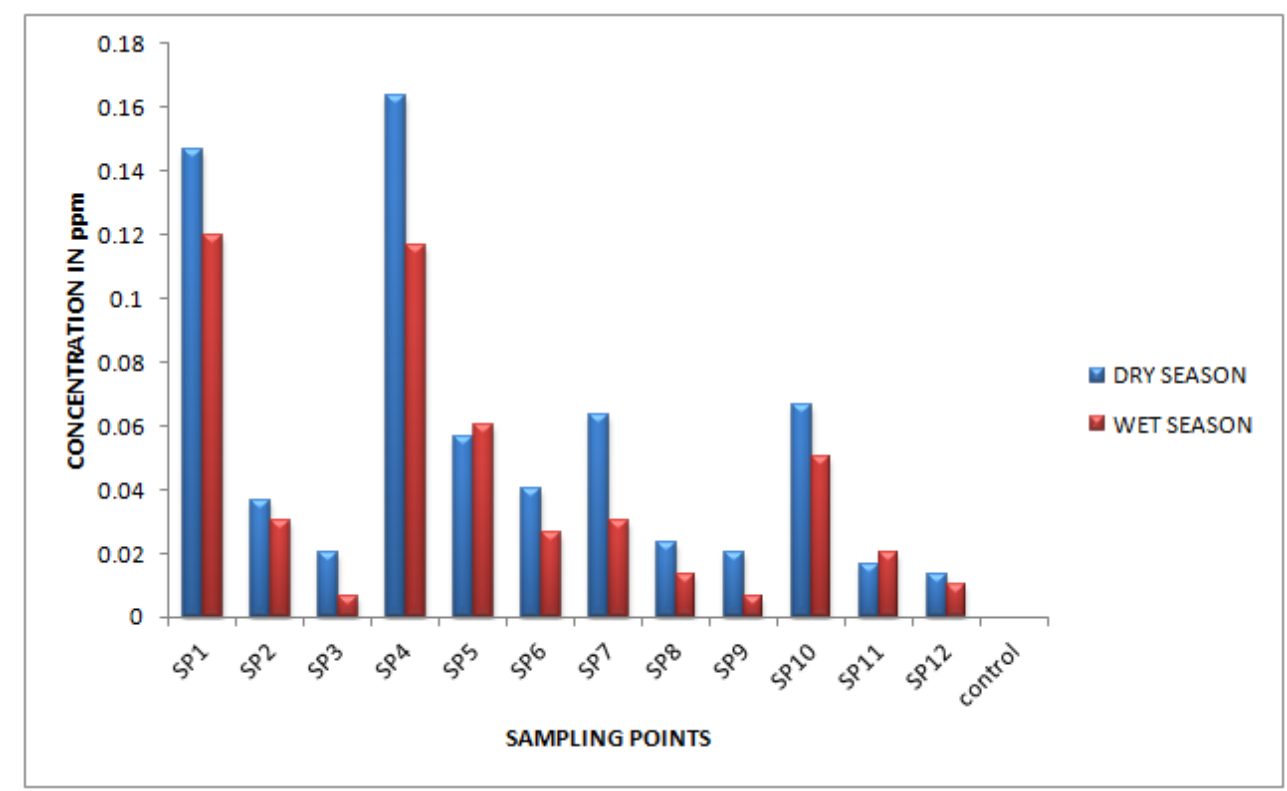

Figure4. Distribution of $\mathrm{SO}_{2}$ in some locations within the vicinity of Kaolin milling plant

Figure 2 showed the distribution of $\mathrm{CO}$ within the vicinity of Kaolin milling plant. $\mathrm{CO}$ has dry season mean concentration of $6.81 \pm 2.05 \mathrm{ppm}$ with variability coefficient of $30.1 \%$ and wet season mean concentration of $6.50 \pm 2.50 \mathrm{ppm}$ with variability coefficient of $38.5 \%$. The highest concentration of $\mathrm{CO}(10.8 \pm 0.66 \mathrm{ppm})$ was found at SP1 while the lowest concentration $(3.7 \pm 0.36 \mathrm{ppm})$ was found at SP9 for the dry season. The wet season has the highest concentration of CO $(11.76 \pm 0.21 \mathrm{ppm})$ at SP4 while the lowest concentration $(3.33 \pm 0.58 \mathrm{ppm})$ at SP8, SP9 and SP12. The pair wise mean seasonal variation between the dry and wet season showed the level of $\mathrm{CO}$ at all the sampling points were statistically significant except for SP9 $(\mathrm{P}<0.05)$. The highest concentration of $\mathrm{CO}$ was detected at SP4 during the wet season. This may be due to the electrical generating set which is used as the main source of power at the milling plant and also the cold weather which always occur during the wet season. Carbon monoxide levels typically are highest during cold weather, because cold temperatures make combustion less complete and cause inversions that trap pollutants close to the ground (US EPA, 2014).

The air quality index for CO in the dry season showed SP9 and SP10 are in the good region (0-50) while all others are in moderate region (51-100). The wet season air quality index showed SP8, SP9 and SP12 are in the good region (0-50), SP1, SP4 are in the region of unhealthy for sensitive group (101-150) and all other sampling points in the moderate region (51-100).

Carbon monoxide (CO) is formed by incomplete combustion of carbon-containing fuels and photochemical reactions in the atmosphere. The most important source of $\mathrm{CO}$ emissions to the atmosphere are from transportation. The World Health Organization (WHO) guidelines for carbon monoxide in the ambient atmosphere and The United States Environmental Protection Agency has air quality standards for carbon monoxide is $9 \mathrm{ppm}\left(10 \mathrm{mg} / \mathrm{m}^{3}\right)$ as an 8-hour average concentration (US EPA, 2009a and WHO, 2000 cited in Kindzierski, et al., 2009). Nigeria Federal Environmental Protection Agency (FEPA) standard for CO is10ppm (Robert, 2015). Robert (2015) found the concentration of $\mathrm{CO}$ in Port-Hacourt metropolis, Nigeria to range between $36.07 \pm 2.6 \mathrm{ppm}$ and $14.3 \pm 0.7 \mathrm{ppm}$. Abam and Onachuckwu (2009), found the concentration of $\mathrm{CO}$ in the range of 3.3$8.7 \mathrm{ppm}$.

Figure 5 showed the distribution of $\mathrm{NO}_{2}$ within the vicinity of Kaolin milling plant. $\mathrm{NO}_{2}$ has dry season mean concentration of $0.053 \pm 0.047 \mathrm{ppm}$ with variability coefficient of $88.6 \%$ and wet season mean concentration of $0.04 \pm 0.026 \mathrm{ppm}$ with variability coefficient of $65 \%$. The highest concentration of $\mathrm{NO}_{2}(0.147 \pm 0.015 \mathrm{ppm})$ was found at SP4 while the lowest concentration $(0.013 \pm$ $0.006 \mathrm{ppm}$ ) was found at SP3, SP9, SP12 for the dry season. The wet season has the highest concentration of $\mathrm{NO}_{2}(0.077 \pm 0.02 \mathrm{ppm})$ at SP1 while the lowest concentration $(0.013 \pm 0.006 \mathrm{ppm})$ was found at SP6. No significant difference in the pair wise mean seasonal concentration of $\mathrm{NO}_{2}$ at all 
sampling points except for SP4 $(\mathrm{P}<0.05)$. The air quality index of $\mathrm{NO}_{2}$ showed the concentrations of SP7 and SP10 in the moderate region (51-100), SP1 and SP4 are in the unhealthy for sensitive group region (101-150) while all other sampling points in the good region (0-50) for both dry season. All the sampling points in the wet season are in the good region (0-50) except for SP1, SP4, SP7 and SP10 which are in the moderate region (51-100).

The World Health Organization (WHO) guidelines for nitrogen dioxide in the ambient atmosphere are $106 \mathrm{ppb}\left(200 \mu \mathrm{g} / \mathrm{m}^{3}\right)$ as a 1-hour average concentration, $21 \mathrm{ppb}\left(40 \mu \mathrm{g} / \mathrm{m}^{3}\right)$ as an annual average concentration (WHO, 2005 cited in Kindzierski, 2009). The United States Environmental Protection Agency has an annual average air quality standard for nitrogen dioxide is $53 \mathrm{ppb}\left(100 \mu \mathrm{g} / \mathrm{m}^{3}\right)$ as an annual average concentration (US EPA, 2009a cited in Kindzierski, et al., 2009). The Occupational Safety and Health Administration (OSHA) set a limit of $25 \mathrm{ppm}$ for Nitric Oxide in workplace air during 8 hours working day; the ceiling limit is a 15 -minute exposure limit of $5 \mathrm{ppm}$ for Nitrogen dioxide in workplace air. (ATSDR, 2002). The concentration of $\mathrm{NO}_{2}$ of vehicular emissions in selected areas in Calabar is $0.04-0.15 \mathrm{ppm}$ (Abam and Onachuckwu, 2009).

Figure 6 showed the distribution of $\mathrm{SO}_{2}$ within the vicinity of Kaolin milling plant. $\mathrm{SO}_{2}$ has dry season mean concentration of $0.056 \pm 0.045 \mathrm{ppm}$ with variability coefficient of $80.4 \%$ and wet season mean concentration of $0.041 \pm 0.045 \mathrm{ppm}$ with variability coefficient of $109.7 \%$. The highest concentration of $\mathrm{SO}_{2}(0.163 \pm 0.08 \mathrm{ppm})$ was found at $\mathrm{SP} 4$ while the lowest concentration $(0.013 \pm$ $0.01 \mathrm{ppm}$ ) was found at SP12 for the dry season. The wet season has the highest concentration of $\mathrm{SO}_{2}$ $(0.12 \pm 0.01 \mathrm{ppm})$ at SP1 while the lowest concentration $(0.007 \pm 0.006 \mathrm{ppm})$ was found at SP3 and SP9. No significant difference in the pair wise mean seasonal concentration of $\mathrm{SO}_{2}$ at all sampling points except for SP4 $(\mathrm{P}<0.05)$. The air quality index in the dry season for $\mathrm{SO}_{2}$ showed SP3, SP8, SP9, SP11 and SP12 in the good region (0-50), SP2, SP5, SP6, SP7 and SP10 in the moderate region (51-100) while SP1 and SP4 are in the unhealthy for sensitive group region (101-150). The wet season air quality index showed all the sampling point are in the good region (0-50), except SP5 and SP10 which are in the moderate region (51-100) and SP1, and SP4 in the region of unhealthy for sensitive group (101-150).

The World Health Organization (WHO) guidelines for sulphur dioxide in the ambient atmosphere are: $191 \mathrm{ppb}\left(500 \mu \mathrm{g} / \mathrm{m}^{3}\right)$ as a 10 minute average concentration and $7.6 \mathrm{ppb}\left(20 \mu \mathrm{g} / \mathrm{m}^{3}\right)$ as a 24-hour average concentration (WHO, 2005 cited in Kindzierski, et al., 2009). The United States Environmental Protection Agency has air quality standards for sulphur dioxide are $140 \mathrm{ppb}$ (366 $\left.\mu \mathrm{g} / \mathrm{m}^{3}\right)$ as a 24-hour average concentration and $30 \mathrm{ppb}\left(79 \mu \mathrm{g} / \mathrm{m}^{3}\right)$ as an annual average concentration (US EPA, 2009a cited in Kindzierski, et al., 2009). The concentration of $\mathrm{SO}_{2}$ of vehicular emissions in selected areas in Calabar is $170-260 \mu \mathrm{g} / \mathrm{m}^{3}$ (Abam and Onachuckwu, 2009).

\section{CONCLUSIONS}

The concentration of CO was highest at SP1 in dry season with the value of $8.33 \pm 0.58 \mathrm{ppm}$ and at SP4 in the wet season with the value of $11.97 \pm 0.21 \mathrm{ppm}$. The concentration of NO was highest at SP4 in dry season with the value of $0.147 \pm 0.02 \mathrm{ppm}$ and at SP1 in the wet season with the value of $0.077 \pm 0.02 \mathrm{ppm}$. Also the concentration of $\mathrm{SO}_{2}$ was highest at SP4 in dry season with the value of $0.163 \pm 0.04 \mathrm{ppm}$ and at SP in the wet season with the value of $0.12 \pm 0.01 \mathrm{ppm}$. The Air quality index (AQI) of all the pollutants was at the region of Unhealthy for sensitive groups at SP1 and SP4 while at other sampling points it was from moderate to Good.

The overall comparison of data for different sampling points showed that concentration of pollutants is highest at SP1 and SP4 due to the proximity to the milling plant and the major road. The study therefore concludes the activity of the Kaolin milling plant can be a source of air pollution with possible severe health consequences.

\section{REFERENCES}

Abam, F.I. and Onachuckwu, G.O. (2009). Vehicular Emissions and Air Quality Standards in Nigeria. European Journal of Scientific Research Vol.34 No.4, pp.550-560

ATSDR (2002). Nitrogen Oxides, Public health statement..Agency for toxic substance and disease registry, division of toxicology and human health science. http://www.atsdr.cdc.gov/toxfaq.html. 
Determination of Some Pollutant Gases in Ambient Air of the Vicinity of a Kaolin Milling Plant in Alkaleri, Bauchi State, Nigeria

ATSDR (2016). Hydrogen Sulphide, Public health statement..Agency for toxic substance and disease registry, division of toxicology and human health science. www.atsdr.cdc.gov/

Kindzierski, W.B., Chelme-Ayala, P. and Gamal El-Din, M.(2009). Ambient air quality data summary and trend analysis part I main report for Wood Buffalo environmental association Fort McMurray, Alberta.

Narayanan, P. (2009). Environmental Pollution: Principle, Analysis and Control. Published by Satish Kumar Jain and produced by Jain, V.K for CBS Publishers and Distributors Pvt Ltd, India. pp 47.

Robert, J.J. (2015). Comparison of Carbon Monoxide Concentrations with Set Standards: A case study of PortHarcourtmetropolis, Nigeria. The International Journal Of Engineering And Science (IJES) Volume 4 Issue 10 pp 48-54.

US EPA (2014). Air quality index. U.S Environmental Protection Agency office of air quality planning and standard outreach Triangle park, N.C.

US EPA (2016) Airnow air quality index calculator. https://www.airnow.gov

Citation: A. Abdullahi et al., "Determination of Some Pollutant Gases in Ambient Air of the Vicinity of a Kaolin Milling Plant in Alkaleri, Bauchi State, Nigeria", International Journal of Advanced Research in Chemical Science (IJARCS), vol. 4, no. 12, pp. 1-6, 2017. http://dx.doi.org/10.20431/2349-0403.0412001

Copyright: (C) 2017 Authors. This is an open-access article distributed under the terms of the Creative Commons Attribution License, which permits unrestricted use, distribution, and reproduction in any medium, provided the original author and source are credited. 